\title{
中立軸補強による極めて短い梁の塑性変形能力改善 IMPROVEMENT OF PLASTIC DEFORMATION CAPACITY OF SHORTER BEAMS WITH FLAT BAR ON THE NEUTRAL AXIS
}

\author{
鈴 木 敏 郎*1, 五十嵐 規矩夫*2，薩川恵一*3，小崎＼cjkstart均*4 \\ Toshiro SUZUKI, Kikuo IKARASHI, Keiichi SATSUKAWA \\ and Hitoshi OZAKI
}

\begin{abstract}
Authors suggested the method to attach flat bar on the neutral axis as one method to improve plastic deformation capacity of the beam in the past study. This paper describes that plastic deformation capacity of the extremely shorter beams is improved by this suggested method, and shows the reason why plastic deformation capacity of beam is improved by attaching with flat bar. The web shear buckling strength is clarified by the difference of the attached shapes of flat bar on the neutral axis, by considering Saint Venant torsion. The optimum shape of flat bar which attach on the neutral axis of beams is investigated by finite element method. To verify the optimum shape of flat bar, the test of the beam with neutral axis reinforcement is carried out. The effect of the reinforcement steel plate on the plastic deformation capacity of the beam is clarified by analytical and experimental approach.
\end{abstract}

Keywords : beam, stiffening, shear buckling, plastic deformation capacity, Saint Venant torsion 梁，補強，せ九断座屈，塑性変形能力，サンブナンネ゙゙り

\section{1. 序}

著者らは, 既往の研究において, H 形鋼梁の塑性変形性能を改善 するう法として，梁の中立軸上に補強部を設けることを提案してき た (1)ー3)。その具体的な手法は，中立軸部に鋼板を添接するものであ り，その有効性を確認してきている。これまでの一連の研究の中で， 対象としてきた梁の多くは，フランジ塑性化の進展とともにウエブ に塑性化が進行するいわゆる曲げ応力支配型の梁であった。しかし， 近年では構造形式を連結する梁や，間柱型の的震要素のように，曲 げ応力よりもせん断応力が卓越する厳しい条件下での極めて短い部 材も使用されるようになってきている。このような部材ではせん断 応力下に扔ける十分な塑性変形能力が要求される。そこで本研究で は, このような厳しいせん断応力下に扔ける梁の塑性変形能力を改 善する手法として，極めて短い梁に対しても中立軸補強を行うこと を提案し，その塑性変形性状と補強材のかかわりを明らかにする。

中立軸に補強子る鋼板は, 梁に存在吋る曲げ応力度とせん断応力 度の比で必要長さを確保する必要があることが既往の研究で明らか になっているる。これにもして本研究で対象とする梁のように, 梁 に作用するせん断応力が曲げ応力に比して遥かに大きい場合なぞ は, 梁全長にわたる補強が必要になる。本研究では, 補強材は梁全 長にわたることを前提とする。

*1秼構造材料研究会 代表. 工博

*2 東京工業大学:大学院理工学研究科建築学専攻 助教授・博士 (工学)

*3 東京理科大学理工学部建築学科 助手. 博士 (工学:)

*4 侏) 日建設計・東京
ところで梁全長にわたる補強を施すのであれば，ウエブ自体の板 厚を增し，ウエブの耐荷能力自体を上げることも考えられるが，単 に板厚を増すことは必ずしも，梁の塑性変形能力を向上るせる上で 得策ではないと考之ている。四 1 を例に用いてその背景を述べる。 使用した梁の断面形状, 解析で用いている鋼材の材料特性などは図 中に記している。注中○で示すものは，せん断スパン比が約 1.5 の逆 対称曲げを受ける梁に作用するせん断力と部材角の関係を，ウエブ 幅厚比をパラメータとして数値解析により求めた結果を示したもの である。ここで对象としているようにせん断応力度の影響が大きな 梁の塑性変形能力を向上させようとした場合には, ウエブの幅厚比 を小さくするべく，ウエブ板厚を厚くする手法が採られるのが常で ある。実際, 本解析結果からもその効果は得られており，塑性変形 能力は向上している。しかし, その最大耐力は上昇し, ウエブ板厚 の違いが荷重変位関係全体の違いとなって現れてきており，それぞ れの梁の最大耐力は, 全てウエブせん断座屈耐力により決定されて いる。このウエブせん断座屈耐力により決定されているか否かは， ○で示した解析結果より判断することができる。○の解析結果は, フランジ板要素を弾性に保つように設定し，ウエブには，ほぼ純せ ん断力が作用するようにモデル化したものである。この梁の最大耐 力は，ウエブのせん断座屈耐力で決定していることは容易に想像で

Kozozairyo Kenkyukai Co., Ltd., Representative, Dr. Eng.

Assoc. Prof., Dept. of Architecture and Building Engineering, Graduate School of Science and Engineering, Tokyo Institute of Technology, Dr. Eng.

Research Assoc., Dept. of Architecture, Faculty of Science and Technology, Tokyo Univ. of Science, Dr. Eng. Nikken Sekkei, Co., Ltd. 
きるが, このようにフランジを弾性としてモデル化した梁と，フラ ンジの塑性化を許容した梁の最大耐力は概ね一致している。これに 加之て, 最大耐力後の耐力劣化性状も大変類似した傾向を示してい る。したがって，フランジに塑性化を許容した梁においても，せん 断スパン比が小さく，ウエブに作用するせん断応力度の影響が大き い場合には，その最大耐力はウエブの純せん断座屈耐力で決定され ていると判断できる。

以上，せん断応力の影響が大きい梁の最大耐力は，ウエブのせん 断座屈耐力で決定される場合が多く，梁の塑性変形能力を向上させ るべくウエブ板厚を厚くした場合においても，その最大耐力はウエ ブのせん断座屈耐力で決定されることに代わりはない。このため, 梁の降伏荷重，最大耐力を大きくかえることなく，その塑性変形能 力を向上させるためには，単に梁の崩壊を決定づけているウェブの 板厚を厚くすることのみで対応するには，ある程度の限界がある。

本諭文では，ウエブのせん断座府酎力で梁の崩壊が決定づけられ るようなせん断伈力が支配的な梁に対して，著者らがこれまで提案 してきた中立軸、にに鋼板を添接する方法で朔性変形能力を问.上させ ることが叮能であることを述べる。ここでは，単にその效果を述べ るにとどまらず，学性湾形能力を们卜させている装四についても検

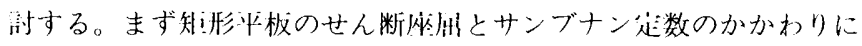

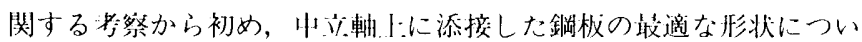

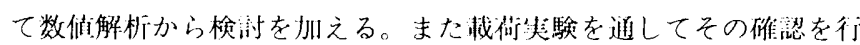

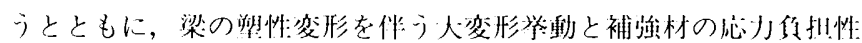

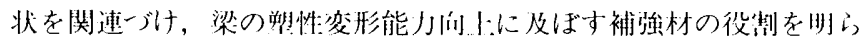
かにする。

2. 矩形平板のせん断座屈耐力に及ぼすサンブナンねじり定数の影響

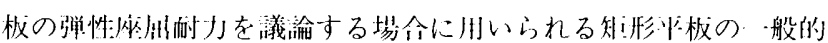
な力の釣令いう程式は，以トのような形で䘚される。

$$
\frac{\partial^{4} w}{\partial x^{4}}+2 \frac{\partial^{4} w}{\partial x^{2} \partial y^{2}}+\frac{\partial^{4} w}{\partial y^{4}}=\frac{1}{D}\left(N_{x} \frac{\partial^{2} w}{\partial x^{2}}+2 N_{x y} \frac{\partial^{2} w}{\partial x \partial y}+N_{y} \frac{\partial^{2} w}{\partial y^{2}}\right) \cdots(1)
$$

ここで, $w$ : 面外変形, $N_{x}: x$ 少吤力, $N_{y}: y$ 方向力, $N_{x y}$ : 通内

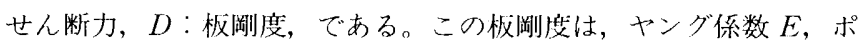
アソン比レ，板序 $t$ を用いて次のように表される。

$$
D=\frac{E t^{3}}{12\left(1-\nu^{2}\right)}
$$

この板剛度 $D$ は, 板の曲げのみが考慮されているような形で表現 されているが, 式(1)の左辺，第 2 項は板のねじりに関わる項であり，

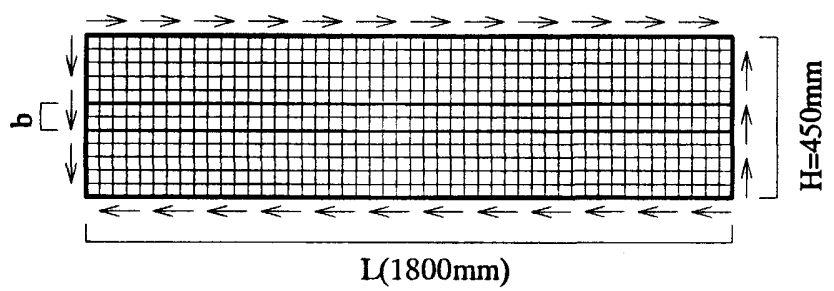

図 2 解析モデル

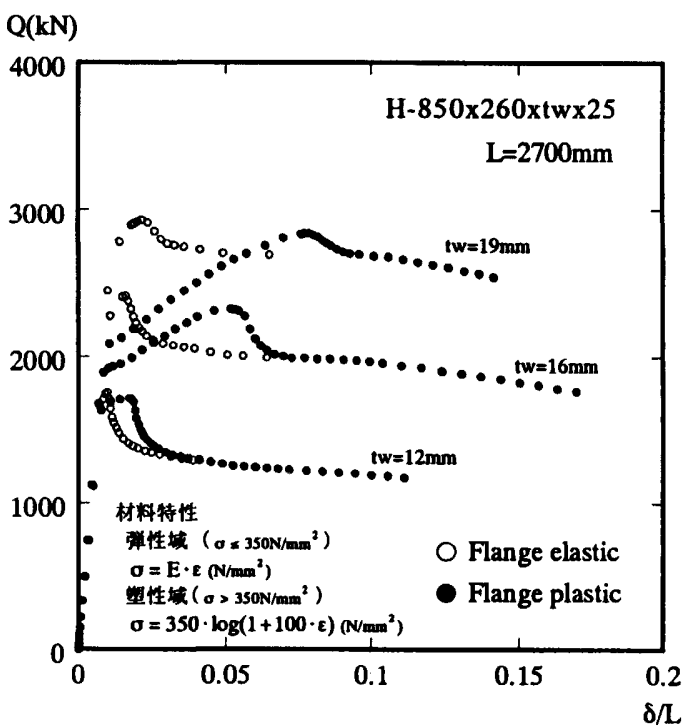

図 1 荷重変位関係

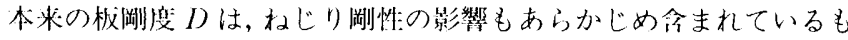

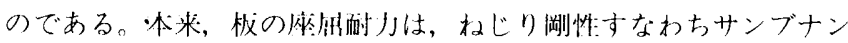

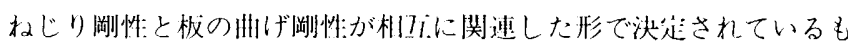
のである。しかし，最終的な板の座朋耐力は，板成度 $D$ と幅原比で

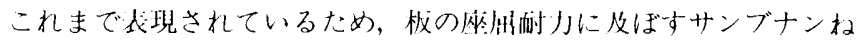
じり㴊性の影辨は暧昧なまま現在に至一ていると思われる。

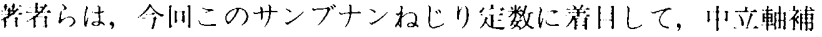
強の效果を考えていく。前提としては，サンブナンねじり䦌性をあ げることで，せん断忍力度の影響が大きな梁の朔性湾形能力を向上 させることができるのではないかと考え，考察を進めていく。

まずここでは，純せん断応力度が作用する矩形平极の夾井耐力と サンブナン定数の関係を考察する。図 2 が数值解析に用いたモデル

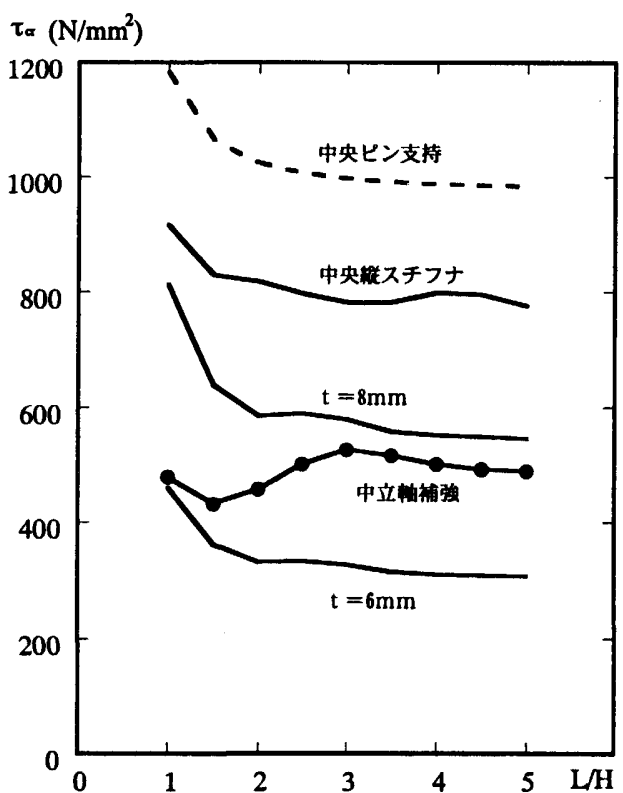

図 3 弾性固有値解析結果 


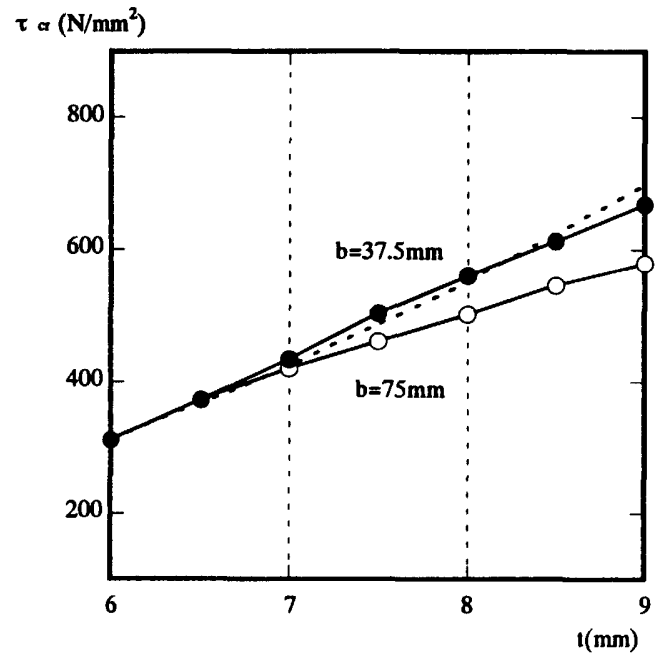

せん断座届応力度

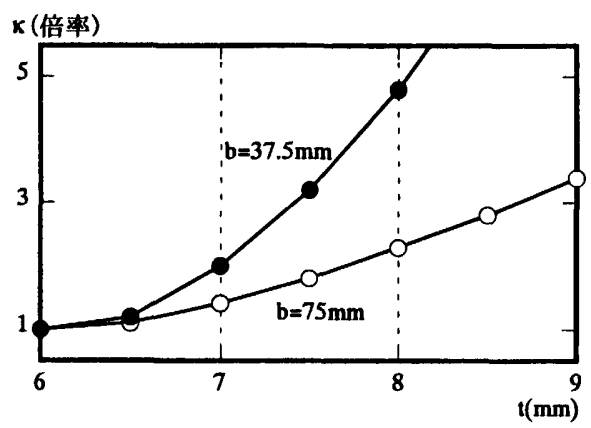

サンブナンねじり定数

図 4 板厚を変化させた場合

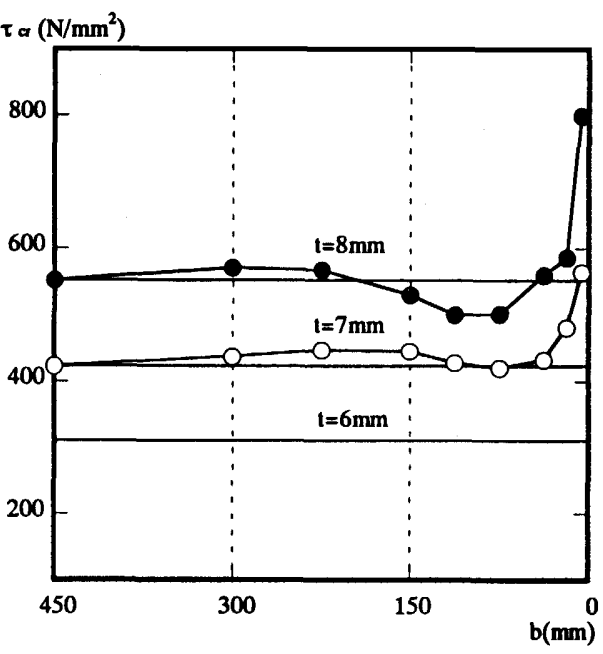

せん断座屈応力度

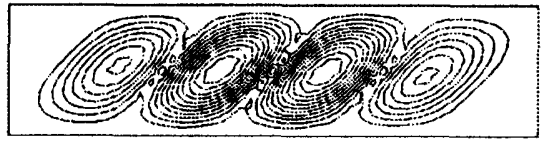

（a）無補強平板（板厚 $8 \mathrm{~mm}$ )
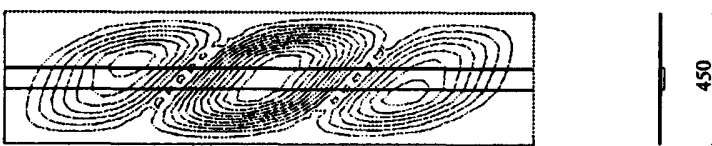

（b）中立軸補強平板（板幅 $75 \mathrm{~mm}$, 板厚 $12 \mathrm{~mm}$ ）
である。矩形平板の 4 辺は面外のたわみ変形および回転変形が拘束 された固定支持としている。この矩形平板が，純せん断力を受ける 場合の座屈耐力を弾性固有值解析により求めている。平板板厚の変 化ならびに平板に添接される各種補強材の諸条件下における座屈耐 力を検討した。

図 3 にその結果を示す。縦軸には，せん断座屈応力度 $\tau_{c r}$ をとり, 横軸には辺長比 $L / H$ をとっている。一番下の実線が板厚 $t=6 \mathrm{~mm}$ の結果であり,下から 3 番目の実線が板厚 $t=8 \mathrm{~mm}$ の結果である。 その間にあるのを結ぶ実線が, $6 \mathrm{~mm}$ の平板に $8 \mathrm{~mm}$ の平板と鋼材量 が等洒な断面に相当するように，幅 $75 \mathrm{~mm}$, 板厚 $12 \mathrm{~mm} の$ 帯板を中立 軸上に添接して補強した場合の結果である。補強された平板は，板 厚が $6 \mathrm{~mm}$ と $8 \mathrm{~mm}$ のものとの間にあり，辺長比 $L / H$ が 3 以上で は, 板厚 $8 \mathrm{~mm} の も の に$ 近い值となっている。この理由として, 辺長 比が短い範囲では，带板が添接されていない平板領域でせん断座屈 応力度が決定されるため, 平板板厚 $6 \mathrm{~mm}$ に近づき, 辺長比が大きく なるにつれて, 帯板がせん断耐力を負担していき, 辺長比 3 付近で, 帯板を含めた平板全体でせん断力を負担し，一様な板厚の矩形平板 のせん断座屈応力度に近づくと考える。

さらに図中上部にある点線で示した值は，平板を上下に分断する 中央位置を理想的なピン支持とした板厚 $6 \mathrm{~mm}$ の場合の解析結果で
ある。この場合座屈波形は上下に完全に分断されるため幅厚比が小 さくなり, 座屈耐力は, 中央をピン支持していないものに比べて大 幅に上昇する。また，その下の実線は板厚 $6 \mathrm{~mm} の$ 平板上下中央に平 板の表裏面からそれぞれ補強板 $(37.5 \mathrm{~mm} \times 12 \mathrm{~mm}$ の板) が垂直に添 接されたスチフナ補強のものである。この補強は，本研究で対象と 寸る補強形式に比べて座屈応力度はかなり高いものの，点線で示し たものよりは低くなっている。これはこのスチフ十位置で平板の面 外への変形が完全には拘束されておらず，平板の座屈変形とともに スチフナもねじれるように変形するためである。

以上，この四 3 の結果は以下のようにまとめることができる。純 せん断応力を受ける平板の上下中央に帯板を添接する場合，平板に 垂直に配されるスチフナ形式のものの座屈耐力が最も高くなるが, 带状に中央位置の板厚を厚くする場合でも，断面積が等価な断面と 同程度の座屈耐力を確保することが可能である。しかしこれらは， あくまでも弾性座屈耐力に関する結果であり, 梁の塑性変形能力に 関しては，スチフナ形式の場合の塑性変形能力が劣ることを後ほど 亦す。

さらに，板厚增厚形式の補強方法について，もう少し詳細な検討 を加えていく。図 4 の上図は矩形平板の板厚を段階的に上げたとき のせん断座屈応力度の変化の様子を示したものである。これは辺長 
比 $L / H$ が 4 の場合について示している。図中点線は, 板厚を一様に 変化させた場合であり，2 本の実線は板厚 $6 \mathrm{~mm}$ を基準にして, 板厚 增加分を中央軸上に補強材幅 $b$ を一定として添接した場合の結果 である。○を結ぶ実線は，補強材幅 $75 \mathrm{~mm}$ とした結果であり，○を結 ぶ実線は補強材幅 $37.5 \mathrm{~mm}$ とした結果である。三者の板厚変化に伴 うせん断座屈応力度の変化は, 良く似た傾向を示している。したがっ て，座属耐力に関していえば，中央位置に断面を集中させて配置す ることは，全体的に平板の板厚を厚くすることに等しいととらえる ことができる。図 4 の下四は, 板厚変化に伴うサンブナンねじり定 数の変化であり, 補強板を添接した平板全体の值と一様な平板の值 との比として示したもので，以下に示す式(3)により算出している。

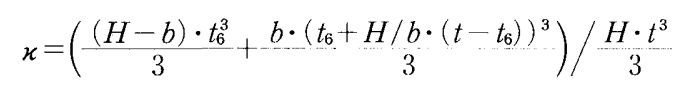

\section{ここで, $t_{6}=6 \mathrm{~mm}$}

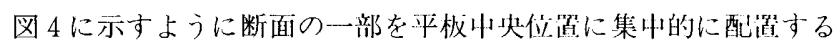
ことで，平板全体のサンブナンねじり定数は鈳めて大きくなること がわかる。これら上下 2 つ図より，断面の一部を中央位置に集中 的に配置していることで, 大半の残りの部分の板原は溥いままであ

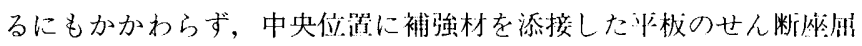
応力度が，平均的に板厚を恃くした塨令のものと间程度となってい ることは, サンブナンねじり菦数の大きな変化によるものであると 考えられる。

次に，補強材の板幅と权りを少化させて解析した絬果を汹５に小 す。平板板厚を $6 \mathrm{~mm}$ とし，圴等にした場命の板占が $7 \mathrm{~mm}$ 及び $8 \mathrm{~mm}$

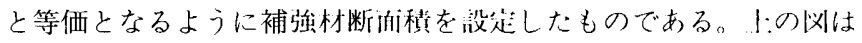
縦軸にせん断座屈応力度をとり，横軸には補強材幅をとって，補咆 材形状がせん断座屈応力度に及ばす影繁をぶしている。は恢紧が

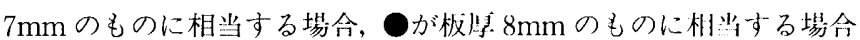
を示している。補強材幅の変化に对してせん断夾州心力度は萑下変 化するものの, 補強材の形状が変化しても基準となる平板板煌での 座屈酎力は, 両解析ともにほぼ維持されている。しかし基淮となる 平板板厚 $8 \mathrm{~mm}$ に招いて, 補強材幅が狭い領域で基淮柀骂のせん断 座屈応力度に比べて低くなっている筒所がある。

図 5 下図は，一様な板厚 $8 \mathrm{~mm}$ にした場合の知形平板(a)と補強材 幅75mm, 板厚12mm が添接された場合の平板(b)の一次固有モ一ド をそれぞれ示したものである。上図に示している基集板厚となる一 様な板厚 $8 \mathrm{~mm}$ の場合では 4 波形，補強材が添接される場合では 3 波形でているのがわかる。つまり補強した塨合でも, 補強材位置で 板の変形を完全に拘束するわけではなく，その結果として固有モ一 ドによってはせん断座屈応力度が低くなると思われる。また一様な 板厚 $7 \mathrm{~mm}$ を基準とした場合には, 補強材形状によらず, せん断座屈 応力度が低くならないことがわかる。このことから一様な矩形平板 の板厚が上がるほど，中立軸での拘束条件が緩くなっていると考之 られる。そして補強材幅が極めて小さくなり，その位置での板変形 を拘束するようになると, 図 3 で示したように中央縦スチフナがつ いた平板のせん断座屈応力度に近づくものと思われる。しかし，こ のスチフナ形式の補強では, 塑性域において変形性能を改善すると いう点において効果が小さいことならびに弾性座屈耐力を向上させ る手法と塑性変形能力を向上させる手法は必ずしも一致しないこと
を次章において示す。

\section{3. 極めて短い梁の塑性変形能力と中立軸補強鋼板とのかかわり}

前章では純せん断応力を受ける平板に対して，弾性座屈酎力を考 えることで上下中央位置を鋼板で補強することに対する効果を検討 してきた。ここでは，せん断曲げを受ける短い梁を対象にして，中 立軸補強効果を検討する。その補強鋼板の形状と塑性変形能力のか かわりについて,サンブナンねじり定数との関係を通して考察する。 ここでは数值解析により検討する。

検討する中立軸補強形式を図 6 に示寸。本補強方法としては補強 鋼板の幅広面をウエブの面に添接することを原則としており，補強 材の配置はウエブの片面でも両面であってもよい。また四に示す 4 タイプはいずれも，補強鋼材量は等しく設定している。この補強材

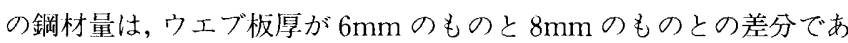
る。この差分の鍋材量を带板の形状に変え，板厚 $6 \mathrm{~mm}$ のウエブ中立 軸にに配置している。この補強を施す梁は，梁せい $450 \mathrm{~mm} ，$ せん断 スパン比が約 $2.3 の$ 片持ち梁である。この梁のフランジ性状と中立軸 補強形式が梁の塑性変形能力に与之る影響について検㣙する。

汹 7 の梁はウエブのせん断降伏が先行し，その後フランジの塑性 化が梁固分端僛から進行寸る。これらの梁の弹朔性举動では，補強

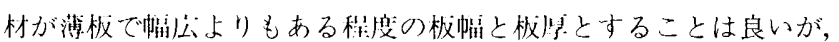

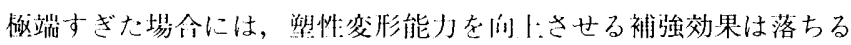

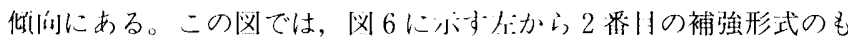
のが，一霍前性変形能力が人きくなっている。これに取して，ウ工

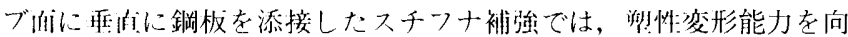
、ささせる效果は，小さいことがわかり，曲げせん断破燷に对寸る補 強としてはあまり效果的ではない。

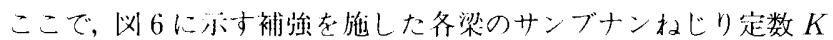

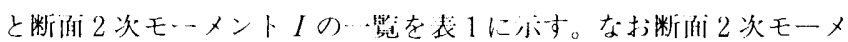
ントは，ウエブ軜回りで筷川している。サンブナンねじり定数も断

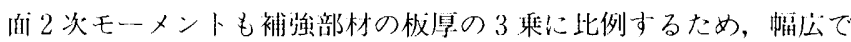
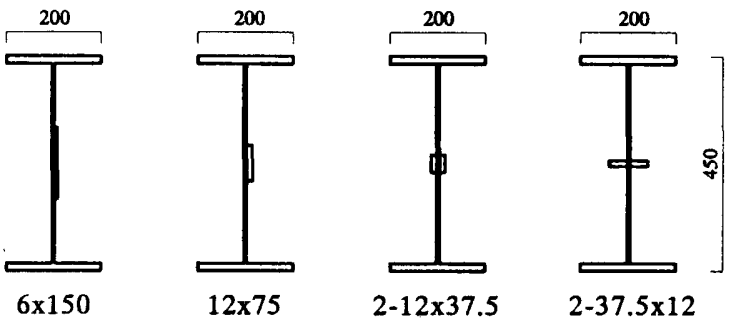

図 6 中立軸補強形式

\begin{tabular}{l|c|c|c|c} 
補強材寸法 $t \times b$ & $6 \times 150$ & $12 \times 75$ & $\begin{array}{c}24 \times 37.5 \\
(2-12 \times 37.5)\end{array}$ & $\begin{array}{c}75 \times 12 \\
(2-37.5 \times 12)\end{array}$ \\
\hline サンプナンねじり定数 $K\left(\mathrm{~cm}^{4}\right)$ & 8.64 & 14.58 & 33.75 & 4.32 \\
\hline 断面二次モーメント $I\left(\mathrm{~cm}^{4}\right)$ & 2.16 & 3.65 & 8.44 & 53.14
\end{tabular}




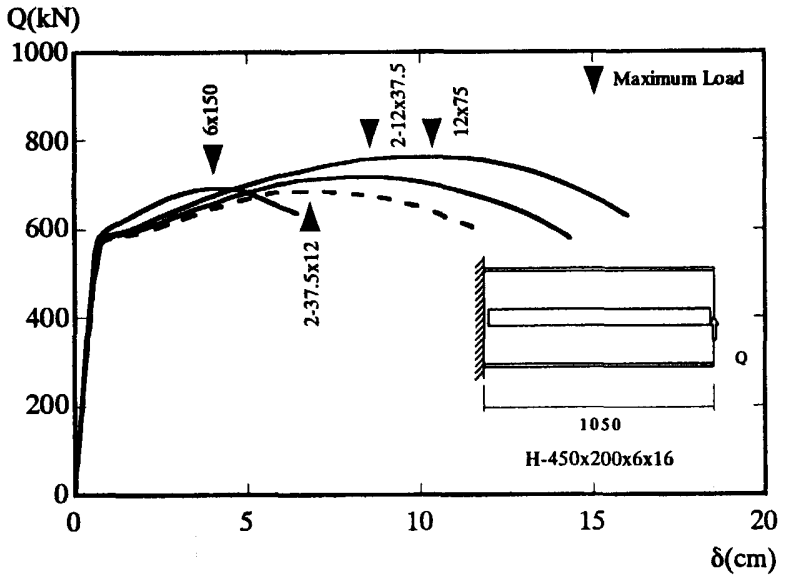

図 7 荷重変位関係 $\left({ }_{w} Q_{p} / Q_{p}=0.92\right)$

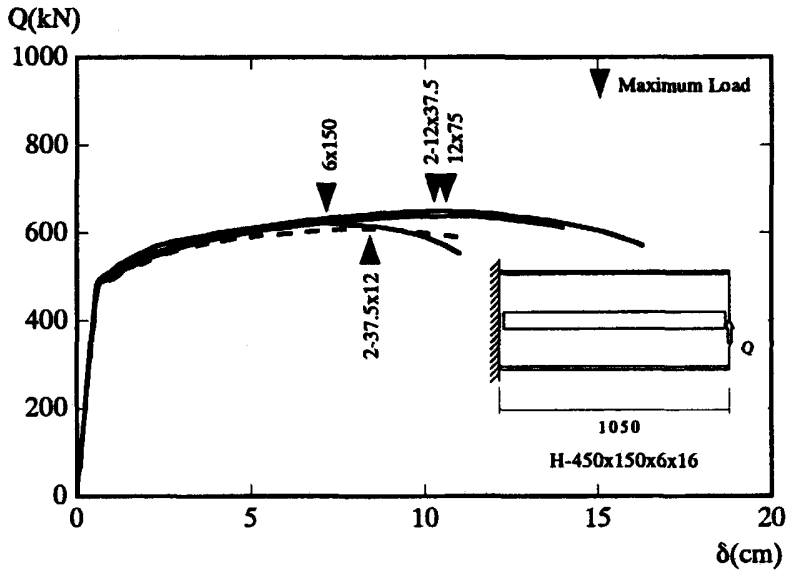

図 8 荷重変位関係 $\left.{ }_{(}{ }_{w} Q_{p} / Q_{p}=1.17\right)$
薄板のものより，狭くて厚さのある方がより大きい。したがって， 図 7 に示す 4 つの補強形式の違いによる比較からわかるように，ウ エブ塑性化以降のせん断耐力は補強材の剛性に応じて変化している ことがわかる。サンブナンねじり定数と断面 2 次モーメントがいか ような比率で座屈耐力に関与しているかは議論の残るところである が，サンブナンねじり定数がある程度大きい補強を施したものが, 断面 2 次モーメントが一番大きい補強よりも塑性変形能力が大きく なっていることは大変興味樑い。

図 8 は, フランジ断面積を小さくし，フランジの曲げ降伏が先行 する梁に対して中立軸補強を施した場合の結果である。図 7 の結果 と比較して, 補強材形状による荷重変位関係の差異は小さくなって いるものの，その傾向は同じであり，塑性変形能力を向上させるた めには，補強材をある程度の板厚，板幅に制限する必要があること にかわりはない。

これら, 図 7, 図 8 の結果から, 前章での純せん断応力下におけ る弾性座屈耐力と異なり, 曲げせん断応力下では, 塑性変形能力を 向上させる上で補強材の風性が大きくなりすぎても効果があがらな い。これは塑性化以降のウエブに発生する座屈波形が中立軸位置に 配置した補強材により上下に分断され，小さな座屈波形となるため であると考えられる。特にスチフナ補強のように極端に曲げ剛性の みが大きい場合も同様な結果になったものと思われる。

以上， $2 ， 3$ 章からの結論として，ウエブのせん断座屈酎力を上 げるためには, 補強材のサンブナンねじり定数, 断面 2 次モーメン トを上げることが効果的であるが, 塑性変形能力を向上させるとい う点においては，必ずしもそうではない。面外変形を抑える断面 2 次モーメントはある程度低くしておき，サンブナンねじり定数を上 げることで塑性変形能力の向上につながる。

\section{4. 極めて短い梁に対する中立軸補強効果と補強材の役割}

前章までの考察において，ウエブの座屈耐力及び梁の塑性変形性 状に及ぼすウエブ上下中央及び中立軸位置に添接した補強鋼板の形 状の影響を明らかにし，より効果的な補強形状を類推することがで きた。本章では, 一部載荷実験結果を用いて, 補强鋼板の補強効果 への役割について考察していく。
まず，前章での考察をもとに，載荷実験を行った。試験体は，図 9 に示すものであり, 補強材の形状は, 前章で効果的な補強材形状 であると判断されたものを用いている。具体的には，H-450×200× $6 \times 16$ の梁に対して, 板厚 $12 \mathrm{~mm}$, 板幅 $75 \mathrm{~mm}$ の帯板をウエブ片面に 全周すみ肉溶接で添接している。この補強材の鋼材量は，一様にウ エブ板厚を $8 \mathrm{~mm}$ とした場合と $6 \mathrm{~mm}$ の場合の差分に相当するもの である。また端部のフランジには, 曲げ降伏しないようカバープレー 卜を全周すみ肉溶接で補強している。

載荷形式は, 図10に示すように, 雨端単純支持とし, 梁中央に載 荷するものである。ただし，試験体となる側が先に降伏するよう， 載荷ビーム側を長くし，試験体側より作用せん断力が小さくなるよ

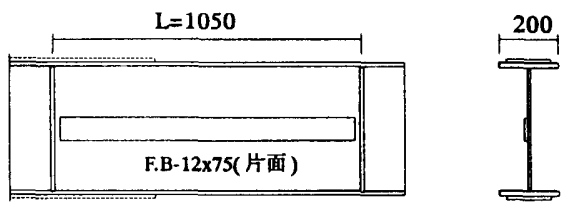

図9試験体四

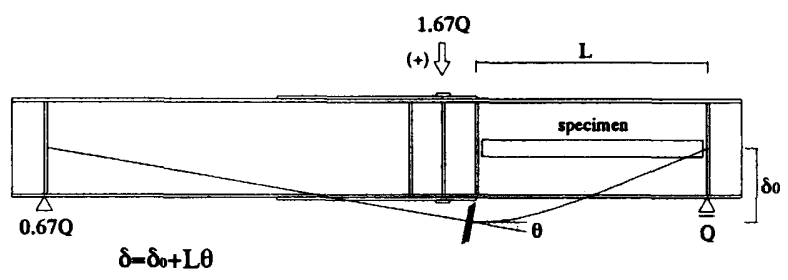

図10 載荷概念図

表 2 鋼材の機械的性質

\begin{tabular}{|c|c|c|c|c|c|c|}
\hline Test-piece & $\begin{array}{c}\mathrm{t}(\mathrm{mm}) \\
\text { 板原 } \\
\end{array}$ & $\begin{array}{c}\sigma \mathrm{y}(\mathrm{N} / \mathrm{mm} 2) \\
\text { 降伏起力度 }\end{array}$ & $\begin{array}{c}\sigma \mathrm{u}(\mathrm{N} / \mathrm{mm} \mathbf{m}) \\
\text { 引張强鹿 }\end{array}$ & $\begin{array}{c}\mathrm{E}(\mathrm{kN} / \mathrm{mm} 2) \\
\text { ヤンク事 }\end{array}$ & $\begin{array}{c}\varepsilon u(\%) \\
\text { - 㥞俥ひ }\end{array}$ & 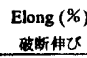 \\
\hline \multirow{2}{*}{ SM4S } & 6 & 362 & 362 & 205 & 17.9 & 25.1 \\
\hline & 12 & 324 & 324 & 204 & 18 & 28.4 \\
\hline
\end{tabular}


うにしている。荷重形式は単調載荷である。また, 以降の考察にお いては, 試験体側の片持ち梁としての変位を用いるため, 端部回転 を考慮した図中の式を用いて端部変位を補正している。また，荷重 は，試験体部に作用するせん断力で考察を進める。

使用鋼材は, 梁, 補強材ともに SM490であり, 引張試験より得ら れた機械的性質を表 2 に示寸。ただし，フランジに関しては，弾性 状態を保つことを前提としているため，引張試験を行っていない。

図11に載荷実験より得られた荷重変位関係を示す。比較のために ウエブに中立軸補強を施していない梁の荷重変位関係を数值解析に より求め示している。また図中には, ウエブ $6 \mathrm{~mm}$ の場合のウエブせ ん断降伏耐力 ${ }_{w 6} Q_{p}, 8 \mathrm{~mm}$ の場合のせん断降伏耐力 ${ }_{w 8} Q_{p}$ を示して いる。

補強材を有する梁と有しない梁の荷重変位関係は，ウエブ板厚が $6 \mathrm{~mm}$ の場合のせん断降伏耐力を若十超之る程度まで同様な関係と なっている。しかし，補強材を有しない梁は，その後急激に耐力少 化する。これはウエブ降伏に伴うせん断座屈によるものである。こ れに対して補強材を有する梁は, 緩やかに耐力上界を続け，ウエブ 板厚が $8 \mathrm{~mm}$ の場合のせん断降伏耐力近くまで最人耐力が至ってい る。またその後の耐力劣化も補強材を有しない梁の壦命に比べて緩 やかである。

このように補強材を盾する梁は多起的な举動を小゙すとになる

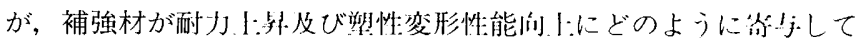
いるかを図12に亦す断面内のせ九断少少度分布から将然する。この 龱に示方応力度分存は, 試験体のウエブ及び補强忉に貼付したUず みゲージより求めたものである。1:に监ぶ 4 つの分炣汹は, 試験体

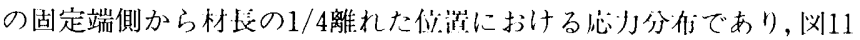
の何重変位関係にホしたた(a)〜(d)の時点におけるものである。また， トの 4 つのものは, 最大耐力時の汹11中の試験体モデル汹に亦す(1) 〜(4)の各断面における伈力分布を示している。

荷重変位関係が弾性時の(a)の応力度分布では, 補強材の上下に位 置するウエブが主にせん断忠力を負担している。このウエブ部分の 応力度が增え, せん断降伏応力度に到達した時点で, 何重変位関係 の公配が変化する。この時点(b)は，ほぼウエブ $6 \mathrm{~mm}$ のせん断降伏耐 力に一致守る。その後, 緩やかな勾配による耐力上昇過程(c)におい て, 補強材がせん断応力の増加分を負担している。さらに荷重の上 昇とともに, 補強材部のせん断応力負担は増え, 補強材がせん断降 伏すると同時期(d)において荷重変位関係は最大耐力となる。

また最大耐力時においては, 補強材の上下のウエブは全ての断面 位置においてせん断降伏耐力に達しているのはもちろんのこと, 補 強材は各断面においてせん断忘力を負担している。しかし，全ての 断面での補強材がせん断降伏しているわけではなく，(2)，(3)の断面 でせん断降伏しているものの，(1)，(4)の断面ではせん断降伏してい ない。これは, 次に示す最終変形状態を示した写真 1 から類推でき る。

写真 1 は最終変形状態を示したものであり，片持ち梁変位として は, $80 \mathrm{~mm}$ を超える程度の変形である。この写真をみると, 補強材の 上下に位置するウエブ部分には，せん断変形が集中して発生してい るのが確認できる。しかし，ウエブの面外への変形は，ウエブ全体 にわたるものではなく，補強材が面外変形を拘束している様子が見 て取れる。また，先ほどの忘力度分布図において，補強材の応力負

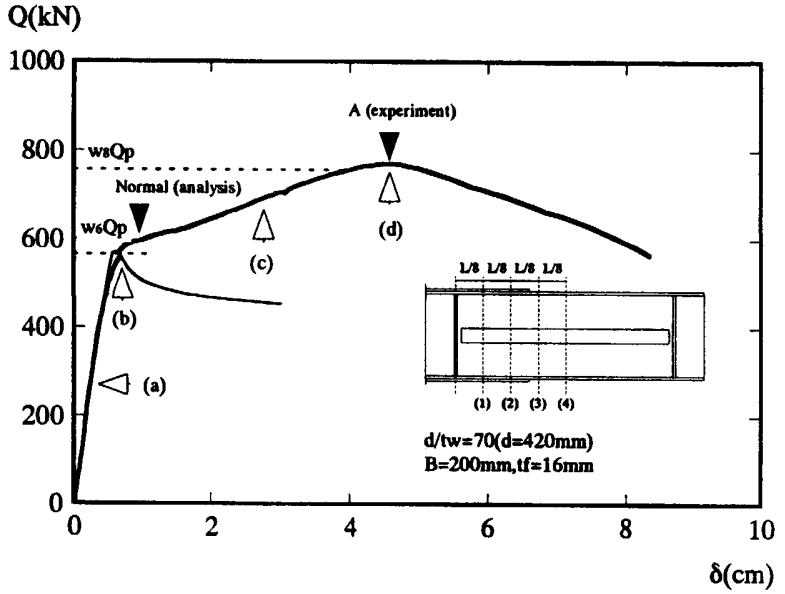

図11 衔重変位関係

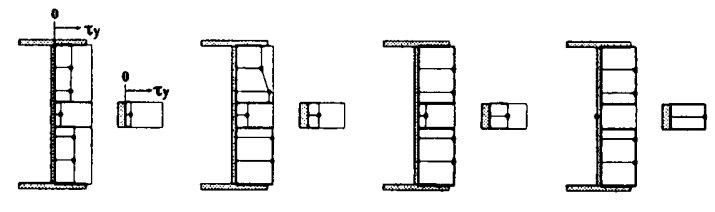

(b)

(c)

(d)

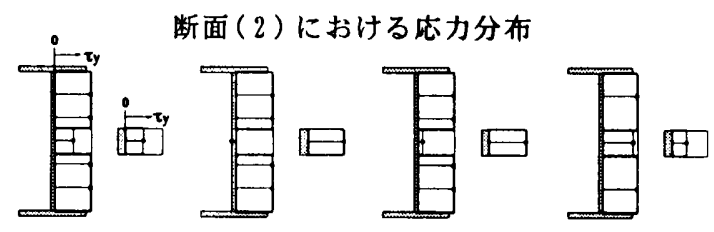

(1)

(2)

(3)

(4)
図12 せん䉼忘力分仍洞

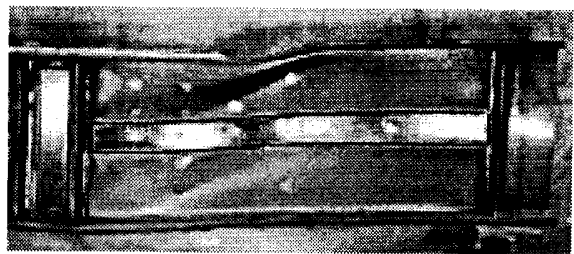

写真 1 最終変形状態

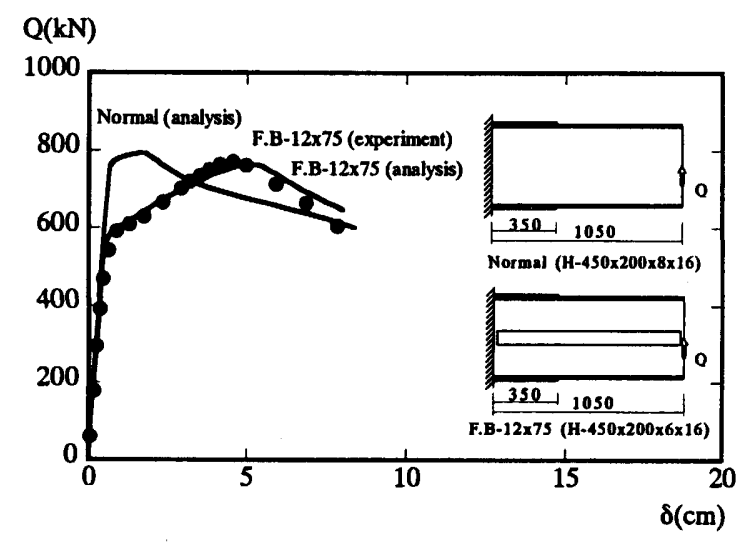

図13実験と解析との対応 


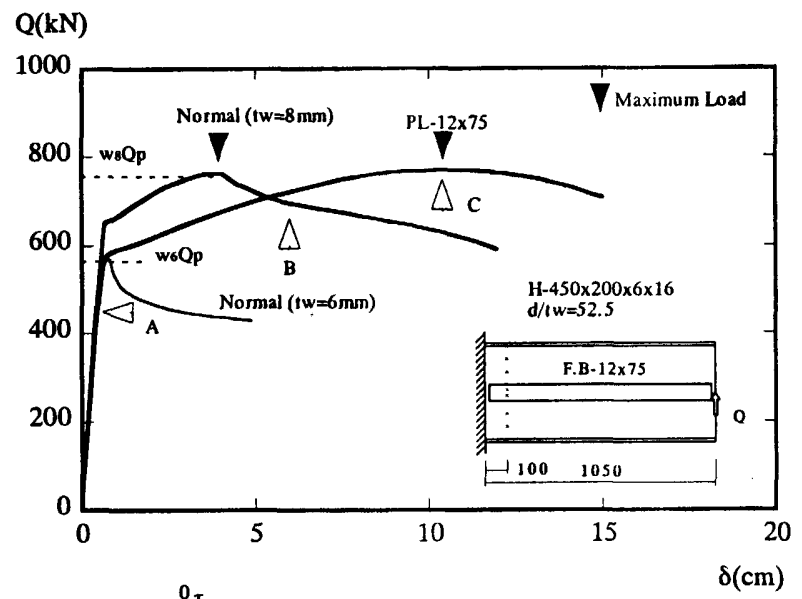

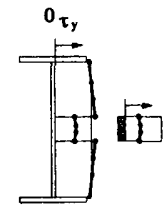

A

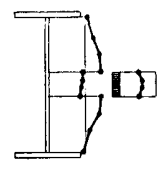

B

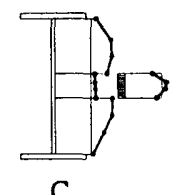

C
図14 荷重変位関係 $\left({ }_{w} Q_{p} / Q_{p}=0.92\right)$

担が大きかった位置(2)，(3)に扮いて，ウエブの面外変形が大きい。 したがって，この位置では，上下ウエブの面外変形の成長により， ウエブでの応力負担は限界に達し, 応力上昇分を補強板が負担し, 荷重変位関係が四11の(b)から(d)と緩やかな勾配で移っていく。しか し，この(2)，(3)の位置で補強材が降伏すると同時に最大耐力となる。 このように補強材は，ウエブが補えなくなった耐力上昇分をウエブ 全体の面外変形を抑えつつ補うことから, 梁としては, ウエブ降伏 後の緩やかな耐力上昇につながるものと考えられる。

次に，フランジの端部での塑性化を許容した場合に，梁の荷重変 位関係と補強材の応力負担性状を検討する。この検討は数值解析を 用いて行うが, この検討に先立ち, 数值解析の妥当性と, 先の実験 の意義についてまず触れておく。

眓13は実験結果と数值解析結果の妥当性並びにウエブを均等に厚 くした場合の荷重変位関係を示したものである。まず，数值解析の 妥当性についてであるが, で示した実験結果とその近傍に位置す る実線の数值解析結果は，極めて良く一致しており本数值解析より 得られた結果は妥当なものであると判断できる。

さらに，ウエブ板厚を均等に厚くしたものと，中立軸補強したも のの違いについて述べる。ウエブを均等にした梁のウエブ板厚は， 先の試験体に添接した板厚 $12 \mathrm{~mm}$, 幅 $75 \mathrm{~mm} の$ 带板分の断面積を $6 \mathrm{~mm}$ のウエブ板厚に増厚した $8 \mathrm{~mm}$ である。以降，罒14，忷15にお いても，フランジの形状は異なった状態であるが,これら両者の荷 重変位関係の比較を行っていく。同時に断面の応力分布性状と荷重 変位関係との関係を考察する。な拉, この補強材形状の選定にあたっ

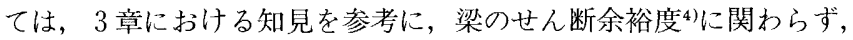
梁の塑性変形能力を向上させるために効果的であった形状としてい る。

困13は，先の載荷垁験と同じようにフランジ端部を補強し，フラ ンジが弾性を保つようにした場合のものである。ウエブ板㫗が $8 \mathrm{~mm}$
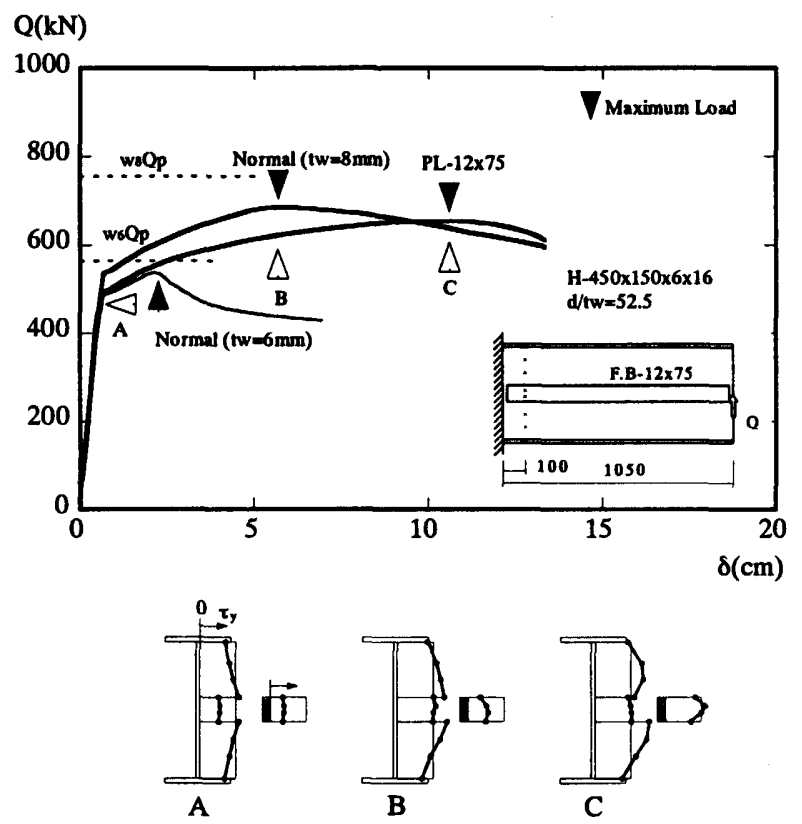

図15 荷重変位関係 $\left({ }_{w} Q_{p} / Q_{p}=1.17\right)$

のものは，ウエブのせん断降伏酎力までせん断力と端部変位の関係 はほぼ線形関係を保ったまま上昇し，せん断降伏耐力を維持したま ま若下変位し，ウエブのせん断座屈により急激に耐力劣化する。こ れに対して，中立軸補強を施したウ工ブ板厚 $6 \mathrm{~mm} の$ 梁の挙動は，先 の実験で見たように，補強を施していない板厚 $6 \mathrm{~mm} の$ 場合のせん 断降伏耐力点近くから塑性化が進行し, 緩やかに耐力上昇を続ける。 この耐力上昇は, ウエブ $8 \mathrm{~mm}$ の場合の绦伏せん断耐力付近まで持 続する。またこの間耐力上昇は緩やかに進行するため，塑性変形も 進行する。また最大耐力後の少化勾配は, ウエブ $8 \mathrm{~mm}$ のものに比較 して緩やかである。

四14はフランジに塑性化が進行するようにした梁の場合である。 ただしウエブ $6 \mathrm{~mm}$ の場合にはフランジの曲げ降伏に先行してウエ ブのせん断降伏が先行するものである。このため, ウエブの塑性化 とともに梁としての塑性変形が進行し，次いでフランジの塑性変形 が加わっていく。この間，中立軸に位置する補強材が降伏後の耐力 上昇に対してせん断応力を負担し，ウエブ全体としてのせん断耐力 を維持するため，大変形領域まで安定した挙動となっている。下図 に梁端部近傍の断面内のせん断応力度の変化を示す。荷重変位関係 につけた記号 $\mathrm{A}, \mathrm{B}, \mathrm{C}$ の時点に拈ける応力度分布を示している。C に示すように, 中立軸上に添接された補強材が負担する応力度がせ ん断降伏応力度に到達した時点と荷重変位関係が最大耐力となる時 点が一致している。これは先のフランジが弾性状態を保つようにし た場合と同じである。

これに対して，ウエブの板厚を均等に $8 \mathrm{~mm}$ とした梁は，ウエブ耐 力を上げ，せん断余裕度を 1.25 としたにも関わらず，塑性変形能力 はウエブ板厚 $6 \mathrm{~mm}$ に補強を施したものに比へて少っている。ま たこのウエブ板厚 $8 \mathrm{~mm}$ にした梁は，せん断余裕度が1.25になった ために，フランジの塑性化が先行することになり，ウエブ板厚 $6 \mathrm{~mm}$ の梁とはその性状が変化している。 
図15はフランジの曲げ降伏が先行する梁の結果である。この例で は，フランジの塑性化が先行し，遅れてウエブにも曲げとせん断に よる塑性化が進行する。この梁の場合も, 先の梁と同様に, 補強材 に生じるせん断応力度が降伏せん断応力度に到達すると同時に, 最 大耐力となっている。またウエブの板厚を均等に $8 \mathrm{~mm}$ まで厚くし た梁は，困14に示した梁と同様に中立軸補強した梁に比べて塑性変 形能力は劣る結果となっている。しかし，降伏耐力の差が，中立軸 補強した梁とウェブ $8 \mathrm{~mm}$ にした梁とでは, 大きくないため, 塑性変 形能力の差も図14の場合ほど大きくなっていない。

\section{5. 結}

本研究では, ウエブに作用するせん断心力が支配的な梁に対して， その塑性変形能力を改善するために梁中立軸上に鋼板を添接する手 法を適用した。その結果, 中立軸補強の効果はせん断応力の作用が 大きな梁に対しても効果的であることが明らかになった。ただし， その形状の選択には注意が必要である。補強材形状として板厚を厚 く，板幅を狭くすることは愬性変形能力を们上させることに份效で あるが，そこにはある程度の制限があることを仃らかにした。また 弾性せん断座周耐力を向上させる補強材形状と塑性変形能力を们上: させる補強材形状は異なる塨命があることを明らかにした。

すなわち水平スチフ十のように板をウエブに乘们に市てるような 場合は極端な例として，これに颣するような柲幅を橔端に狄くした

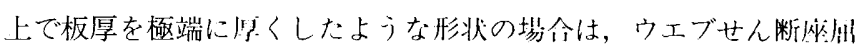
耐力を上げるためには们効であるが，塑州変形能力を问卜させると いう観点からは不邀切な䉼面であることを明らかにした。これは，

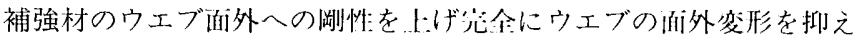
ることで上下に波形を完全に分断古るよりも，ある程度の南外変形 は許容し，ウエブ塑州化に伴う阙州低トをを補強材のサンブナンねじ り剛性で補う方が塑性変形能力の问上には效果的であることをぶする ものである。

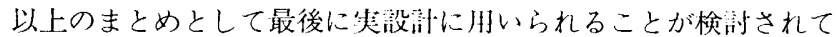
いる極めて短い梁に中間補強材を添按した場合について，数储解惊

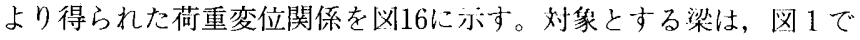
取り上げた断面形状 $\mathrm{H}-850 \times 260 \times 16 \times 25$, 長さ $2700 \mathrm{~mm} の$ 逆対称 曲げを受ける梁である。ウエブが無補強のものの街重変位関係を○ で示し，中間補強を施した梁の荷重変位関係を○で示している。補 強方法は，平鋼の幅広面をウエブの㞹的に添接する夕イプのもので ある。罒に示す $16 \mathrm{~mm} \times 77.5 \mathrm{~mm} の$ 平板を而面に添接した場合の鋼 材量は, 均等にウエブ板厚を $19 \mathrm{~mm}$ とした場合にほぼ等しい。図 1 に

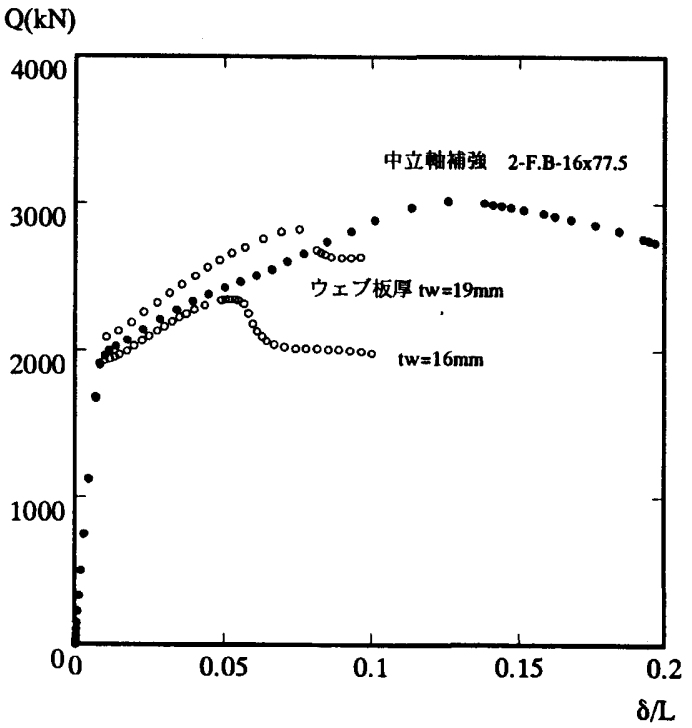

図16 荷重変位関係

もボしているウエブ板厚 $19 \mathrm{~mm} の$ 無補強の梁の侣重変们関係もので ホしている。

無補強の梁に比べて，補強材を添接した梁の前州湾形能力は大き く，最大耐力後の少化幻配も緩やかになっている。また補強材を施

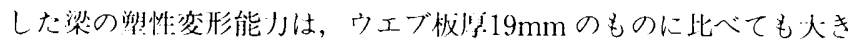

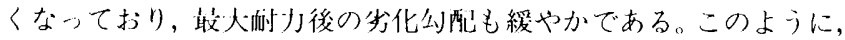

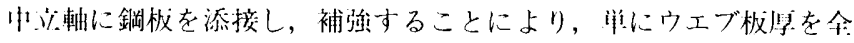

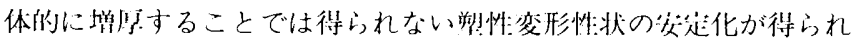
るようになる。

\section{参考文献}

1）鈴木敏郎：鉄少部材の性能を收普寸るための一つの試み，11本建筑学会大

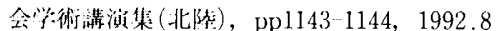

2）鈴木端郎，小汇利行，五十葻規矩夫：ウエブに銅板を添接した $\mathrm{H}$ 型鋼曲げ 部材の㤠性変形性状に関寺る研究，日本建築学会構造系論文集，No.470， pp1 $15122,1995.4$

3）鈴木敏郎，五十嵐規矩夫，薩川恵一，堤康一郎，橋本幸治：中立軸補強に よる $\mathrm{H}$ 形鋼梁の塑性変形能力改善に関する研究，日本建築学会構造系論 文集, No. 574, pp219-225, 2003.12

4）鈴木敏郎, 五十嵐規矩夫, 常木康弘：せん断曲げを受ける $\mathrm{H}$ 形鋼梁の崩壊 形式と塑性変形性能に関する研究, 日本建築学会構造系論文集, No. 547, pp185-191，2001.9

（2004年 7 月 9 日原稿受理，2004年12月15日採用決定） 